\title{
Model Giving Question and Getting Answer Untuk Meningkatkan Hasil Belajar Siswa Sekolah Dasar
}

\author{
Yeni Dwi Kurino \\ Pendidikan Guru Sekolah Dasar, Universitas Majalengka \\ email Yenidwi_kurino@yahoo.com
}

\begin{abstract}
Abstrak—Latar belakang penelitian ini adalah rendahnya hasil belajar Matematika pada pembelajaran Matematika di Sekolah Dasar. Rendahnya hasil belajar tersebut dilihat dari data awal siswa pada pelajaran Matematika, yaitu banyak siswa yang masih dibawah KKM. Dalam hal ini guru mengupayakan agar siswa dalam belajar Matematika dengan menggunakan model pembelajaran Model Giving Question and Getting Answer. Dengan demikian, siswa mampu menemukan Hasil Belajar dengan caranya sendiri untuk memecahkan masalah dalam pelajaran Matematika. Model penelitian yang digunakan yaitu Penelitian Tindakan Kelas. Penelitian ini dilaksanakan dalam dua siklus yang terdiri dari beberapa tindakan yang membahas materi Matematika sekolah Dasar. Berdasarkan hasil penelitian dengan menggunakan model pembelajaran Model Giving Question and Getting Answer, maka Hasil Belajar meningkat. Hal ini terlihat pada tes yang diberikan peneliti kepada seliuruh siswa dikelas V Sekolah Dasar yaitu terdapat peningkatan dari rata-rata nilai Hasil belajar Pada data awal ketuntasan siswa berada pada $11,76 \%$. Selanjutnya, pada siklus I ketuntasan meningkat sebanyak $55,88 \%$ dan ketuntasan siswa pada siklus I menjadi $67,64 \%$. Pada siklus II, ketuntasan siswa kembali meningkat sebanyak $8,83 \%$ dan ketuntasan siswa menjadi $76,47 \%$. Interaksi siswa dengan siswa maupun siswa dengan guru lebih kondusif, Hasil Belajar siswa tiap tindakan selama penelitian berlangsung mengalami peningkatan.
\end{abstract}

\section{Kata kunci: hasil belajar, model pembelajaran Model Giving Question and Getting Answer, pembelajaran Matematika.}




\section{PENDAHULUAN}

Dalam pelaksanaan pembelajaran Matematika yang berlangsung disekolah pada umumnya masih berpusat pada pendidik yang menyebabkan pembelajaran Matematika masih dianggap sebagai pembelajaran yang monoton dan kurang menyenangkan, terlalu banyak hapalan, kurang variatif. Siswa dalam pembelajaran Matematika kurang adanya keterlibatan secara fisik, emosional, maupun psikis karena menganggap mata pelajaran matematika merupakan mata pelajaran yang membutuhkan pemahaman konsep yang luas. Kemudian, pengelolaan kelas masih belum optimal dikarenakan pengaturan tempat duduk dan kesiapan siswa mengikuti pembelajaran dikarenakan pembelajaran yang monoton dan kurang menyenangkan yang menjadikan siswa dalam berinteraksi hanya searah sehingga proses pembelajaran cenderung di dominasi oleh pendidik yang berdampak pada hasil belajar siswa yang rendah.

Proses pembelajaran Matematika lebih menekankan pada aspek pendidikan dari pada transfer konsep, tetapi kenyataan dilapangan pelajaran Matematika dipandang sebagai pelajaran yang membosankan, karena pembelajaran Matematika hanya menghapal rumus konsep-konsep yang berkaitan dengan kehidupan sosial, padahal matematika sangat mereka butuhkan untuk kehidupan mereka karena Matematika bukan hanya transfer ilmu saja tetapi siswa juga dituntut untuk berfikir logis dan kritis, yang salah satu kemampuan itu adalah kemampuan dalam memecahkan masalah (Sapriya, 2009: 194). Suatu masalah membutuhkan suatu kemampuan berpikir dalam upaya memecahkannya. Pembelajaran matematika sangatlah penting dalam mengajarkan kemampuan berpikir memecahkan masalah karena dengan menumbuhkan

kemampuan memecahkan masalah siswa dapat menyelesaikan masalah dalam kehidupan sosialnya.

Hasil belajar yaitu sebagai tingkat keberhasilan siswa dalam mempelajari materi pembelajaran disekolah yang dinyatakan dalam skor yang diperoleh dari hasil tes mengenai sejumlah materi ajar tertentu. Hasil belajar juga merupakan perubahan tingkah laku siswa setelah melalui proses pembelajaran. Semua perubahan dari proses belajar merupakan suatu hasil belajar dan mengakibatkan manusia berubah dalam sikap dan tingkah lakunya. Pada pembelajaran Matematika di kelas V SDN Cijati sebagian besar siswa beranggapan bahwa mata pelajaran Matematika sukar karena hanya menghafal rumus dn latihan. Dalam proses pembelajarannya guru kurang memanfaatkan media sebagai alat peraga dalam proses pembelajaran sehingga menyebabkan hasil belajar siswa rendah.

Berdasarkan hasil observasi di kelas $\mathrm{V}$ sekolah dasar negeri Cijati yang berjumlah 34 siswa yang terdiri dari 18 siswa perempuan dan 16 siswa laki-laki di temukan permasalahan dalam pembelajaran Matematika yaitu rendahnya hasil belajar siswa pada mata pelajaran IImu pengetahuan Sosial menunjukkan bahwa siswa yang sudah tuntas yaitu 4 siswa dan yang belum tuntas yaitu 30 siswa. Berdasarkan kiteria ketuntasan minimal (KKM 61), presentase siswa yang tuntas mencapai $11,76 \%$ atau 4 siswa dan yang belum tuntas mencapai $88,24 \%$ atau 30 siswa. Berdasarkan kondisi tersebut, maka perlu adanya perbaikan proses pembelajaran yang dapat meningkatkan hasil belajar siswa pada mata pelajaran Matematika. Peneliti akan menggunakan model pembelajaran Model Giving Question and Getting Answer . Model pembelajaran ini merupakan suatu 
model pembelajaran yang berpusat pada siswa (student centre) yang dapat meningkatkan pengetahuan siswa dan melatih siswa lebih aktif dalam pembelajaran. Berdasarkan permasalahan tersebut, rendahnya hasil belajar siswa pada pembelajaran Matematika disebabkan pendidik lebih banyak menerapkan metode ceramah sehingga siswa kurang aktif dalam kegiatan belajar mengajar serta kurangnya media pembelajaran yang kongkrit. Oleh karena itu proses pembelajaran belum mencapai tujuan secara optimal.

Penelitian yang mendukung bahwa penerapan model Model Giving Question and Getting Answer dapat meningkatkan hasil belajar terdapat pada penelitian berjudul "Penerapan Model Pembelajaran Model Giving Question and Getting Answer Untuk Meningkatkan Hasil Belajar Ipa Siswa Kelas V Semester Genap" yang dilakukan oleh AA Ngurah Agung Swapranata1, Pt. Nanci Riastini2, I Gst. Ngurah Japa3 123 Jurusan PGSD, FIP Universitas Pendidikan Ganesha Singaraja, Indonesia. Hasil penelitian menunjukkan terjadi peningkatan hasil belajar IPA siswa melalui penerapan model Model Giving Question and Getting Answer .

\section{KAJIAN LITERATUR DAN PEGEMBANGAN HIPOTESIS}

Model pembelajaran Model Giving Question and Getting Answer

Model pembelajaran giving question and getting answer (GQGA) merupakan implementasi dari strategi pembelajaran kontruktivistik yang menempatkan siswa sebagai subyek dalam pembelajaran. Artinya, siswa mampu merekonstruksi pengetahuannya sendiri sedangkan guru hanya bertindak sebagai fasilitator saja. Seperti yang dikemukakan oleh Piaget (Shoimin, 2014: 58)
Belajar yang berbasis konstruktivisme. Pembelajar mengkonstruk sendiri realitasnya atau paling tidak menerjemahkannya berlandaskan persepsi tentang pengalamannya, sehingga pengetahuan individu adalah sebuah fungsi dari pengalaman sebelumnya.

Model giving question and getting answer ditemukan oleh Spancer Kagan, orang berkebangsaan Swiss pada tahun 1963. Menurut Suprijono (2015: 126) model ini dikembangkan untuk melatih siswa memiliki kemampuan dan keterampilan bertanya dan menjawab pertanyaan, karena pada dasarnya model tersebut merupakan modifikasi dari metode tanya jawab dan metode ceramah yang merupakan kolaborasi dengan menggunakan potongan-potongan kertas sebagai medianya.

Model giving question and getting answer dilakukan bersamaan antara metode tanya jawab dengan metode ceramah, agar siswa tidak dalam keadaan blank mind. Metode ceramah sebagai dasar agar siswa mendapatkan pengetahuan dasar (prior knowledge).

\section{Langkah-langkah pembelajaran}

menggunakan model pembelajaran

\section{Giving Question and Getting Answer}

Langkah-langkah model pembelajaran giving question and getting answer menurut Hisyam Zaini, (2008: 67-70) adalah:

a) Buat potongan-potongan kertas sebanyak dua kali jumlah siswa yang ada dalam kelas.

b) Minta setiap siswa untuk melengkapi pertanyaan berikut ini:

Kertas 1: saya masih belum paham tentang.........

Kertas 2: saya dapat menjelaskan tentang..........

c) Bagi siswa ke dalam kelompok kecil, 4 atau 5 orang. 
d) Masing-masing kelompok memilih pertanyaan-pertanyaan yang ada (kartu 1), dan juga topik-topik yang dapat mereka jelaskan (kartu 2).

e) Minta setiap kelompok untuk membacakan pertanyaanpertanyaan yang telah mereka seleksi. Jika ada di antara siswa yang bisa menjawab, diberi kesempatan untuk menjawab. Jika tidak ada yang bisa menjawab, guru harus menjawab.

f) Minta setiap kelompok untuk menyampaikan apa yang dapat mereka jelaskan dari kertas 2 . Selanjutnya minta mereka untuk menyampaikannya ke kawankawan.

g) Lanjutkan proses ini sesuai dengan waktu dan kondisi yang ada.

h) Akhiri pembelajaran dengan menyampaikan rangkuman dan klarifikasi dari jawaban-jawaban dan penjelasan dari siswa.

Dari uraian kegiatan pembelajaran dengan menggunakan model pembelajaran giving question and getting answer di atas, maka peneliti menggunakan model giving question and getting answer dalam pembelajaran matematika.

\section{Hasil Belajar}

Indikator hasil belajar yang akan diukur oleh peneliti hanya pada domain kognitif saja, dengan alasan keterbatasan peneliti dalam hal pengetahuan, waktu dan tenaga. Pada aspek kognitifpun dibatasi juga hanya pada C1, C2, C3 (pengetahuan, pemahaman, penerapan). Karena disesuai dengan psikomotor dilihat dari tahap perkembangan siswa SD menurut Piaget yaitu tahap operasional konkrit (7-11 tahun) dimana pada tahap ini kemampuan siswa belum mampu berpikir logis dan belum mencapai tahap analisis sehingga peneliti mengambil indikator yang sesuai dengan tahap dan perkembangan siswa SD.

\section{METODE PENELITIAN}

Metode yang digunakan dalam penelitian ini Penelitian Tindakan Kelas. Desain yang digunakan dalam penelitian ini adalah desain john Elliot

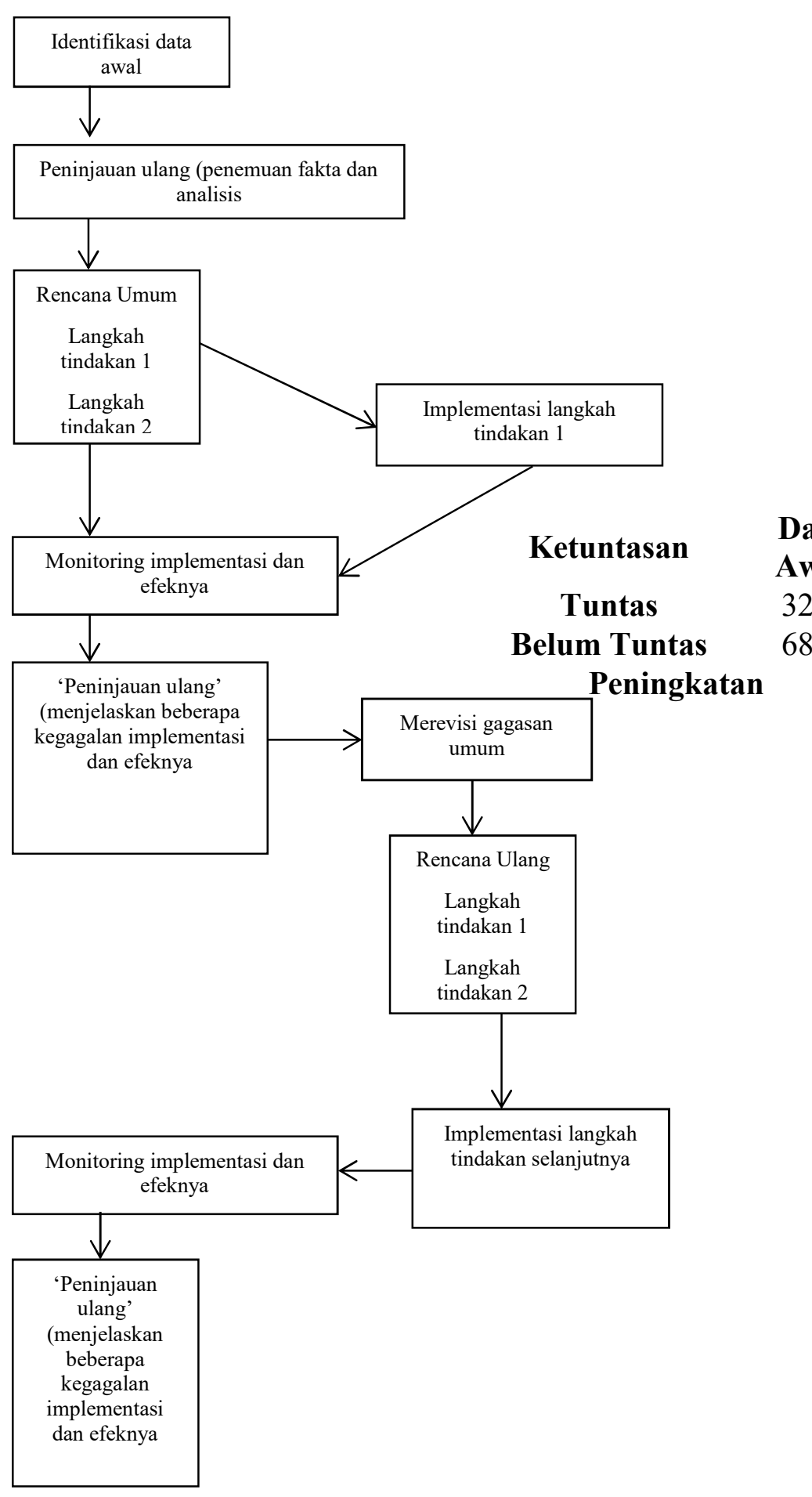

Gambar Alur PTK Model John Elliot 
(Novianti, 2013:54)

\section{HASIL DAN PEMBAHASAN}

Berdasarkan hasil penelitian yang telah dilakukan, terlihat bahwa adanya peningkatan yang baik pada tiap siklus dengan menggunakan model pembelajaran giving question and getting answer pada mata pelajaran matematika pada siswa Sekolah Dasar.

Hasil belajar siswa dengan menggunakan model giving question and getting answer. Adapun pada kondisi awal, siklus I dan siklus II:

\section{Tabel 1}

Rekapitulasi Ketuntasan PerSiklus

\begin{tabular}{|l|c|c|c|}
\hline $\begin{array}{l}\text { Ketuntas } \\
\text { an }\end{array}$ & $\begin{array}{c}\text { Data } \\
\text { awal }\end{array}$ & $\begin{array}{c}\text { Siklu } \\
\text { s I }\end{array}$ & $\begin{array}{c}\text { Siklu } \\
\text { s II }\end{array}$ \\
\hline Tuntas & $\begin{array}{c}11,76 \\
\%\end{array}$ & $\begin{array}{c}67,64 \\
\%\end{array}$ & $\begin{array}{c}76,47 \\
\%\end{array}$ \\
\hline Belum & $\begin{array}{c}88,24 \\
\%\end{array}$ & $\begin{array}{c}32,35 \\
\%\end{array}$ & $\begin{array}{c}23,52 \\
\%\end{array}$ \\
\hline
\end{tabular}

Adapun Secara lebih jelas, rekapitulasi ketuntasan siswa di setiap siklusnya dapat dilihat pada diagram di bawah ini.

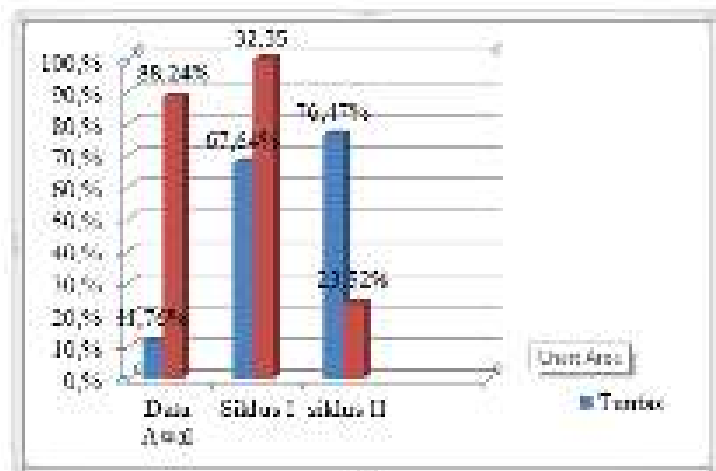

\section{Gambar 2 \\ Diagram Ketuntasan Hasil Tes Siswa Per-Siklus}

Dari tabel 1 gambar 2 diatas, dapat disimpulkan bahwa setiap siklusnya meningkat. Pada data awal ketuntasan siswa berada pada $11,76 \%$. Selanjutnya, pada siklus I ketuntasan meningkat sebanyak 55,88\% dan ketuntasan siswa pada siklus I menjadi $67,64 \%$. Pada siklus II, ketuntasan siswa kembali meningkat sebanyak $8,83 \%$ dan ketuntasan siswa menjadi $76,47 \%$.

\section{KESIMPULAN}

Berdasarkan hasil uraian dan analisis data sebelumnya maka dalam penelitian ini peneliti dapat mengambil kesimpulan penelitian sebagai berikut:

1. Penerapan model pembelajaran giving question and getting answer dapat meingkatkan hasil belajar siswa, hal ini dibuktikan antusias siswa saat pembelajaran matematika yang kondusif dan termoltivasi.

2. Hasil belajar siswa meningkat, hal ini dibuktikan dengan hasil tes siswa yang meningkat setiap sikulusnya.

3. Peningkatan hasil belajar siswa setaip siklusnya meningkat yaitu dengan bukti Pada data awal ketuntasan siswa berada pada $11,76 \%$. Selanjutnya, pada siklus I ketuntasan meningkat sebanyak $55,88 \%$ dan ketuntasan siswa pada siklus I menjadi $67,64 \%$. Pada siklus II, ketuntasan siswa kembali meningkat sebanyak $8,83 \%$ dan ketuntasan siswa menjadi $76,47 \%$.

\section{REFERENSI}

Arikunto, S. (2002). Prosedur Penelitian Suatu Pendekatan Praktek. Jakarta: Rineka Cipta.

Depdiknas. (2003). Undang-undang No 20 Tahun 2003, tentang Sistem Pendidikan Nasional. Jakarta: Depdiknas.

(2004). Peraturan Dirjen Dimyati, M. (2013). Belajar dan Pembelajaran. Rineka Cipta: Jakarta.

Heriawan, A, dkk. (2012). Metodologi Pembelajaran. Banten: LP3G. 
Siregar, E. (2010). Teori Belajar dan Pembelajaran. Bogor: Ghalia Indonesia.

Sudjana, N. (2010). Penilaian Hasil Proses Belajar Mengajar. Bandung: Remaja Rosdakarya. (2013). Dasar-dasar Proses Belajar Mengajar. Bandung: Sinar Baru Algesindo.

Sugiyono. (2009). Metode Penelitian pendidikan (pendekatan kuantitatif, kualitatif dan R\&B). Bandung: Alfabeta.

Suryosubroto, B. (2009). Proses Belajar Mengajar di Sekolah. Jakarta: Rineka Cipta.

Tirtonegoro, S. (2001). Anak Supernormal dan Program Pendidikannya. Yogyakarta: Bumi Aksara.

Trianto. (2011). Model Pembelajaran Terpadu. Jakarta: Bumi Aksara. 